\title{
Handling of Covid-19 as a Non-Natural Disaster in Indonesia
}

\author{
Qurrata Ayuni ${ }^{1}$, Fitra Arsil ${ }^{2}$ \\ \{qurrataayuni@ui.ac.id ${ }^{1}$ \} \\ Constitutional Law Department, University of Indonesia, 16424, Indonesia ${ }^{1,2}$
}

\begin{abstract}
This paper analyzes how Indonesia is handling the global Covid-19 pandemic. This paper focuses on the Indonesian Government's decision to determine the Covid-19 pandemic as a non-natural national disaster. It addresses the questions: is the determination of the status of a non-natural national disaster effectively used in handling Covid-19 in Indonesia? to answer this question, this paper employed juridical normative by exploring the regulations and institutional approaches the pandemic. This paper indicates four pointsfirst, there is a need to strengthen institutions and policies. Second, there is a need to clarify policies both in material and formal terms. Third, there are needs to be a centralization of policy implementers. Fourth, it is necessary to strengthen checks and balances from other branches of power. This paper is essential as part of the evaluation and lessons learned to handle Covid-19 better to produce optimal policies during emergencies.
\end{abstract}

Keywords: Covid-19, non-natural national disaster, the indonesian government

\section{Introduction}

Since discovering the first two cases of Covid-19 (novel coronavirus or SARS-CoV-2) on March 2, 2020, in Depok, the Indonesian government has produced a series of legal products to deal with the spread of Covid-19 [1]. Globally, the World Health Organization (WHO) has designated Covid-19 as a Public Health Emergency of International Concern (PHEIC) on January 30, 2020. After that, the WHO increased its status as a Global Pandemic on March 11, $2020[2]$.

The laws and regulations in Indonesia have provided various alternatives in responding to emergencies caused by this global pandemic. In general, two rules are used as references informing policies for handling Covid-19, namely (Fig. 1) Law Number 6 of 2018 concerning Health Quarantine and Law Number 14 of 2007 concerning Disaster Management.

On March 31, 2020, the Government issued Presidential Decree No. 11 of 2020 concerning the Determination of Public Health Emergencies, which refers to the Health Quarantine Law. This determination is the basis for the imposition of large-scale social restrictions in several regions in Indonesia. On the same date, President Joko Widodo also issued Government Regulation in lieu of Law Number 1 of 2020 concerning State Financial Policy and Financial System Stability for Handling the Corona Virus Disease (Covid-19) Pandemic and/or in the Context of Facing Threats Endanger the National Economy and/or Financial System Stability. Finally, the President issued Presidential Decree No. 12 of 2020 concerning the Designation of Non-Natural Disaster for the Spread of Corona Virus Disease 2019 (Covid-19) as a National Disaster. Several derivative regulations and implementing regulations were established to 
complement the technical legal instruments required by the Covid-19 emergency policy in Indonesia. The reference law can be seen in Figure 1.

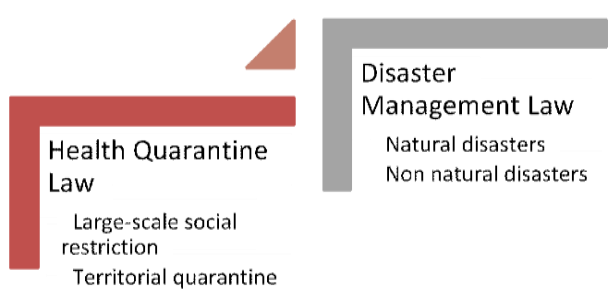

Fig. 1. Reference law

\section{Method}

This paper uses the normative juridical method. Normative juridical research aims to examine legal principles, legal systematics, legal synchronization, legal history, and comparative law. One of the approaches used is "The Doctrinal Approach," which is to explore the opinions of experts and practitioners related to the topics discussed. This paper analyzes government policy towards an emergency using emergency constitutional law theory.

Using juridical and theoretical approaches, this paper compares the needs that should exist in policymaking in an emergency. The main theory used is the emergency powers which should be able to deal with emergencies effectively. The regulatory approach is used to assess the suitability of legal products created by the government with urgent needs during the Covid-19 pandemic.

\section{Result and Discussion}

\subsection{Strengthening institutions and policies}

The concept of determining status in an emergency is to give the government the authority to take the necessary actions to save the country by concentrating resources to restore normal conditions [3]. This concept was initially requested by WHO to Indonesia through a letter on March 10, 2020, one of which asked the Indonesian Government to increase its response to Covid-19, namely establishing a national emergency status [4].

The determination of this emergency status is a form of strengthening institutions and policies that can constitutionally be carried out by the government in an emergency. This strengthening is reflected in the government's ability to produce legal products that are quick and appropriate in responding to crises [5].

Institutional and policy weakening occurs when the government delays in determining the emergency status. Twenty days after WHO's recommendation, the Indonesian government only established a Public Health Emergency on March 31, 2020 [6]. In health calculations, 20 days is too late to be related to the incubation period and the spread of Covid-19, which is around 14 days (Figure. 2) [7]. 


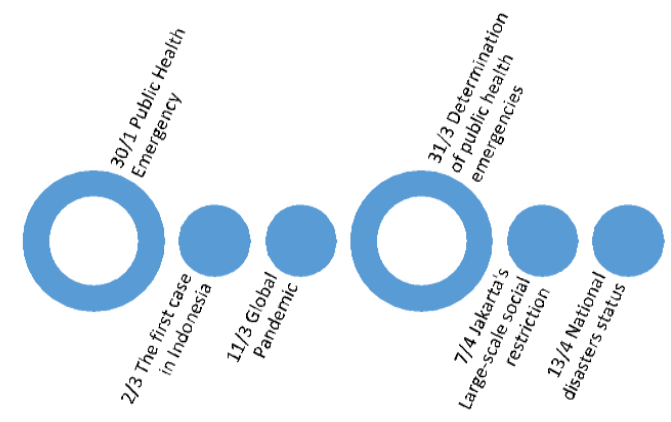

Fig. 2. Activity Covid-19 in Indonesia

The delay in determining this emergency has resulted in a crisis of public confidence by first implementing an informal lockdown before formally establishing the large-scale social restrictions in several parts of Indonesia. In fact, in an emergency, the central government has the constitutional authority to determine crucial policies related to public interests in priority.

Institutional and policy strengthening is the first recommendation in this policy brief to emphasize the government's need to produce legal products that do not overlap, a solution characterized by cutting administrative bureaucracy. The presence of uncertainty regarding government policies will add to the length of the bureaucratic chain. This can be seen from the presence of Government Regulation no. 21 of 2020 concerning Large-Scale Social Restrictions on Covid-19, which in its regulation adds to the length of the policymaking process in times of emergency.

David \& Brenda explain that a bureaucratic approach in implementing emergency management will result in an ineffective emergency response [8]. Institutional strengthening is carried out to control public policies in times of crisis that require high accuracy and high speed. To improve the policymaking process so that it does not drag on.

\subsection{Clarity of the formal-material form of policy}

Another problem found in several legal products related to Covid-19 was the lack of formalmaterial clarity regarding policy formation. One criticism that is often encountered is the lack of content in a legal product born during an emergency. A policy cannot be executed immediately but must wait for a more detailed implementation regulation. A legal product that is born in an emergency must at least have appropriate and applicable content. The content in a legal product stipulated by the government must contain the main things and the details that can become the framework for implementing the policy.

The presence of Government Regulations concerning Large-Scale Social Restrictions (PSBB) and government regulations in lieu of laws 1 of 2020 concerning Covid-19 are examples of rules that do not have sufficient material content. Problem drafting should not make legal products lack content and or even have no exact meaning. The existence of Government Regulation No. 21/2020 is hoped that concerning Large-Scale Social Restrictions cannot provide more administrative requirements than Law No. 6/2018 concerning Health Quarantine. Likewise, other implementing regulations have to facilitate emergency policies and not cause long bureaucratic excesses. 
Similarly, Government regulations in lieu of laws 1 of 2020, which in essence does not have a clear definition of what is meant by "the Framework for Facing Threats that Endanger the National Economy and/or Financial System Stability," so it has the potential to be applied inappropriately. On the other hand, the absence of clear directions reflected in public health policies has confused some stakeholders in taking technical steps. One of them is found in the risk of fraud in the procurement of goods and services that can be categorized as corrupt. The absence of a firm and directed policy makes technical actors worry that they will become victims of maladministration because they are considered to cause losses to state finances.

Formal and material clarity are also crucial in emergency law products to avoid misuse of interpretation and use. So, there is no need for confusion in the community regarding the permissibility or prohibition of going home, the ban of online motorcycle taxis, and the determination of a disaster situation as reasons for source major in a contract. The lack of content in Covid-19 legal products must also be linked to the health policy crisis. So it is necessary to have legal products that are specifically issued to provide guarantees for the availability of more specific and adequate medical and community health devices.

There have not been any public policy products that clearly describe a road map for dealing with Covid-19 in the health corridor. Simultaneously, the need to provide laws and regulations based on public health is one priority in dealing with health emergencies. So, it is necessary to formulate a policy engineering that ensures protection for medical personnel, the availability of medical devices such as masks, PPE, and Covid-19 test kits, as well as policy engineering to ensure the availability of quality and affordable pharmaceutical products. Therefore, legal products issued during an emergency must have applicable content in an exact format so that they are not trapped in the usual administrative mechanisms that are difficult to do in times of crisis.

\subsection{The centralization of policy implementers}

During an emergency, the ideal concept of control is in the theory of Carl Schmitt regarding "The Sovereign" [9]. According to him, an emergency requires strengthening command and centralization of policy implementers. In theory, centralization of control and policy during a crisis can only be carried out by the President as head of state because it is the President who is given constitutional authority to violate the laws that apply specifically during an emergency.

In implementing the Covid-19 emergency, many major players do not have a firm posture of authority. The unclear, leading sector about this authority has resulted in many parties feeling that they have the power to regulate one another. Fig. 3 is several key players in handling Covid19 include the Ministry of Health, the National Disaster Management Agency, the Regional Government, and the Central Government.

Sagar argues that the concentration of power will facilitate good policymaking in an emergency. This is precisely what is expected from the implementation of the emergency status [10]. The existence of Presidential Decree No.11 of 2020 concerning the Determination of the Corona Virus Disease 2019 (Covid-19) Public Health Emergency is expected to centralize policies in response to Covid-19.

The centralization of this policy was later biased due to Presidential Decree No.12 of 2020 concerning the Determination of Non-Natural Disasters for the Spread of Corona Virus Disease 2019 (Covid-19), a National Disaster. These two emergency declarations created a status quo in handling Covid-19.

The determination of Public Health Emergencies authorizes the Minister of Health as the leading sector in policymaking, including large-scale social restrictions. However, at the same 
time, the Determination of Non-Natural Disasters for the Spread of Covid-19 assigns responsibility to the Chairperson of the Covid-19 Task Force, who is also the Head of the BNPB (National Disaster Management Agency). In this status quo condition, it is necessary to be explicit about implementing policies' centralization process so that it does not cause interpretation or even collisions with one or more legislative products.

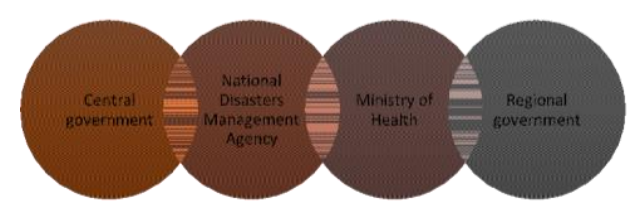

Fig. 3. Key players in handling Covid-19

\subsection{Strengthening checks and balances}

Although, in essence, an emergency is a condition for violating the law, the implementation of an emergency cannot be separated from the checks and balances mechanism. The need to bypass the administrative side in times of crisis must not eliminate other state powers that have been guaranteed in the constitution. The public's biggest concern about the loss of the checks and balances mechanism lies in enacting government regulations in lieu of laws 1 of 2020 regarding irregularities in state finances. The argument for handling Covid-19 or the argument for state financial stability can easily be used to take actions with minimal oversight from both the legislature and the judiciary.

The leniency to relocate state finances can be made to provide fast services in crisis conditions. However, the budget relocation approach must be justified within the corridor of law. So that efforts to relocate budgets and policies can still meet the principles of good governance. Some concerns over Articles 27 and 28 of government regulations in lieu of laws no $1 / 2020$ that eliminate legal remedies through court channels and legislative involvement in Covid-19 / financial stability policymaking are a design of checks and balances incompatible with the current application of emergency law. The need to produce fast and appropriate policies with proportional state budget provisions is also essential in fulfilling citizens' rights in the future.

Rossiter made an inventory of the need for certain limitations in applying emergency law not to create a dangerous constitutional dictatorship [11]. Some people do not use the legal stipulation in the emergency of Covid-19 to save themselves or their group. Still, it is used for the most significant benefit of the Indonesian people.

\section{Conclusion}

Based on the description above, it can be concluded that the Indonesian government needs a number of improvements in dealing with the Covid-19 pandemic. Several issues that need to be considered are the need to concentrate on one policymaker. Besides that, it requires proper policy-making with effective legislative formulations. 
Equally important is the need to ensure that governments do not use emergencies as opportunities to commit fraud. Therefore, the existence of checks and balances is needed in a situation like this. The stipulation of the Covid-19 pandemic as a non-natural disaster does not make BNPB the leading sector, but the existence of various other institutions that are also the leading sector, resulting in a centralized policy administration. So it is necessary to have clarity regarding the leading sector in handling covid-19 in Indonesia.

\section{Acknowledgement}

The author would like to thank Allah SWT for give manifest in this work. "...And when ye are told to rise up, rise up. Allah will raise up to (suitable) ranks (and degrees), those of you who believe and who have been granted Knowledge. And Allah is well-acquainted with all ye do" [Quran, 58:11].

\section{References}

[1] S. Setiati and M. K. Azwar, "COVID-19 and Indonesia," Acta Med. Indones., vol. 52, no. April, pp. 84-89, 2020.

[2] F. Di Gennaro et al., "Coronavirus diseases (COVID-19) current status and future perspectives: A narrative review," Int. J. Environ. Res. Public Health, vol. 17, no. 8, 2020, doi: 10.3390/ijerph17082690.

[3] E. Bulmer, Emergency powers, vol. 18, no. 8695. International Institute for Democracy and Electoral Assistance International, 2018.

[4] A. Hamzah, "Client Update : Indonesia Jokowi Declares Covid-19 as a National Disaster : a Force Majeure Trigger? Client Update: Indonesia," 2020. [Online]. Available: https://www.ahp.id/clientalert/AHPClientUpdate-14April2020-1.pdf.

[5] F. Arsil and Q. Ayuni, "Model Pengaturan Kedaruratan Dan Pilihan Kedaruratan Indonesia Dalam Menghadapi Pandemi Covid-19," J. Huk. Pembang., vol. 50, no. 2, p. 423, 2020, doi: 10.21143/jhp.vol50.no2.2585.

[6] A. G. T. dan A. Sugiharto, "Policy Conflict Between President Joko Widodo and Governor of," Syntax Transform., vol. 1, no. 9, pp. 580-590, 2020.

[7] N. Zaki and E. A. Mohamed, "The Estimations of the COVID-19 Incubation Period: A Systematic Review of the Literature," medRxiv, no. Cdcdc, 2020, doi: 10.1101/2020.05.20.20108340.

[8] D. M. NEAL and B. D. PHILLIPS, "Effective Emergency Management: Reconsidering the Bureaucratic Approach," Disasters, vol. 19, no. 4, pp. 327-337, 1995, doi: 10.1111/j.14677717.1995.tb00353.x.

[9] C. Schmitt, Political Theology: Four Chapters on the Concept of Sovereignty. University of Chicago Press, 2006.

[10] R. Sagar, "Emergency Powers," in The Oxford Handbook of the Indian Constitution, and P. B. M. Sujit Choudhry, Madhav Khosla, Ed. Oxford University Press, USA, 2017.

[11] C. Rossiter, Constitutional Dictatorship: Crisis Government in the Modern Democracies. Routledge, 2002. 